\title{
The Bruce Dynasty, Becket and Scottish Pilgrimage to Canterbury, c.1178-c.1404
}

Historians have long been aware of the widespread popularity of Canterbury Cathedral, Kent, and its principal shrine of Archbishop Thomas Becket (d. 1170), as a site of pilgrimage and as a figure of veneration for non-English subjects in the later Middle Ages. The intensity of human traffic towards the martyr's tomb from several regions of north-west Europe after 1170, and the foundation of numerous monastic houses, smaller churches, hospitals and altars to facilitate liturgical devotion to St Thomas in many of these lands, have already been detailed by modern scholars. ${ }^{1}$ This was clearly a pattern of entreaty of saintly intercession which was sustained well beyond the initial late twelfthand early thirteenth-century flurry of miracula and hagiographical writing associated with Becket and Canterbury. Moreover, although the records of Canterbury Cathedral and the English Crown are weighted towards evidence for upper class interaction with this saint and shrine, there is sufficient data, too, to allow historians and archaeologists to envisage a continuing stream of devotion by the lower social orders of England's neighbour realms in addition to, of course, the ordinary devout people of Canterbury's own hinterland and the wider English kingdom.

It should, then, come as little surprise to identify a remarkable degree of sustained Scottish interest in this famous pilgrimage venue and the potentia of its chief saint. Indeed, modern scholars have already detailed the profound interest shown in Becket by Scotland's Crown, leading nobles and churchmen, during the reigns of William I (11651214), Alexander II (1214-49) and Alexander III (1249-86): this was a period, really, of relative peace between Scotland and England, though often uneasy. ${ }^{2}$ This Scottish 
devotion to St Thomas centred not only upon periodic pilgrimages to Canterbury itself but also the foundation and support in this period of a major monastic house dedicated to the martyr saint, at Arbroath in coastal Angus (Forfarshire). Moreover, this upper class Scottish observance of Becket was matched by the devotions of lesser Scots: this is suggested by the discovery of two thirteenth-century ampullae of Becket's shrine oil water mixed with his blood and brains - in excavations at Perth in central Scotland. ${ }^{3}$

However, recent studies have also remarked in passing that this Scottish focus on Becket was apparently revived after the six decades of the wars of Scottish Independence or Succession (1296-1357). ${ }^{4}$ Robert Bruce's son, David II of Scotland (1329-71), was released from captivity in England in October 1357 upon the agreement of a truce: thereafter, ongoing talks towards a full Anglo-Scottish peace heralded a striking and regular traffic in safe-conduct requests by notable Scots seeking to undertake pilgrimage to and/or through England, very often with the stated destination of Becket's tomb at Canterbury. But this devotional travel is seen to collapse with the resumption of more open, if erratic, Anglo-Scottish border hostilities after the death of Edward III in 1377: such pilgrimage only resurfaced thereafter, it seemed, during truces and through the activities of particular noble families, like the border earls of Douglas and Dunbar/March, or in the reigns of particular kings, for example James I (1406-37) and James IV (14881513), who - like David II - had English wives. ${ }^{5}$ A similar pattern of late fourteenth- and fifteenth-century decline in Scottish interest in Canterbury and Becket might also be posited at the outset for Scotland's ordinary population, alongside a concomitant growth in interest in 'native' Scottish saints like Ninian of Whithorn in Galloway and Duthac of Tain in Ross: this reflected the further cooling of Anglo-Scottish, 'nationalist' relations during the reigns of the first Stewart kings of Scots. ${ }^{6}$ At the same time, the fifteenth- 
century saw a shift in favour away from Becket and instead towards long-distance pilgrimage to other, increasingly more fashionable tombs in England, for example to the shrine of Our Lady at Walsingham in Norfolk or the Holy Blood relics at Hailes Abbey in Gloucestershire: Scots may have preferred after $c .1400$ to integrate visits to these sites, rather than to Canterbury, with their spiritual journeys abroad to, say, the tomb of St John at Amiens, St James at Compostela or to the Holy Land. ${ }^{7}$

Nevertheless, scholars have as yet not investigated in detail and context the range of motivations which had drawn Scots south during this most dramatic of centuries c.1286-c.1406, to seek passage to Becket's tomb and its associated houses, altars and relics at Canterbury (including those of St Augustine, St Dunstan, St Andrew and the Virgin Mary). The recent suggestion that the cult of St Thomas, and in particular its major Scottish dedication foundation of Arbroath Abbey, became something of a 'liability' in Scotland after Edward I's invasion of 1296 and thus declined in popularity would seem to be contradicted by the resurgence of pilgrimage to Becket's tomb once a prolonged period of peace was restored in $1357 .{ }^{8}$ Did the Scottish pilgrims of the second half of the fourteenth-century still seek to make their long and often hazardous journey south for the varied reasons of genuine piety and penance, politics, diplomacy and personal gain which had characterised their devotion before 1296? If so, is this evidence that Scottish interest in Canterbury and St Thomas and his associated cult sites had not waned despite a half century and more of intense and seemingly increasingly ethnicallymotivated war and the end of the genuinely cross-border royal, aristocratic and ecclesiastical land-owning class and culture of pre-1296? Or is it the case that the long national conflict and dynastic politics of the period caused such ostensibly religious traffic south to be further secularised: that is, politicised or otherwise altered, masking 
motives for contact with southern England which were in reality purely diplomatic, territorial, military or economic? If so, does this mean that Scottish pilgrimage to Canterbury could not be a spiritual way of repairing or managing relations between the two realms in the later fourteenth-century?

At the outset, any suggestion that Anglo-Scottish war after 1296 should have drawn Scots to become increasingly equivocal toward St Thomas (and thus Canterbury) seems problematic. From the first, Scotland's monarchy, leading nobles and ecclesiastics may have had decidedly mixed motives for devotion to Becket. Scotland's strongest association with the martyr was, after all, born of defeat in battle against England following the capture of William I at Alnwick in 1174. That reverse had resulted in the imposition of the feudal over-lordship terms of the Treaty of Falaise upon William's person, heirs and realm by Henry II of England whose knights had murderously rid him of his turbulent priest four years earlier. ${ }^{9}$ The legend that Henry had made a penitent journey to Canterbury and prayed before Becket's remains on the very day of William's invasion of Northumberland in collusion with the French, and thus affected the 'miracle' of the Scottish king's defeat and subsequent punishment along with his realm, might easily have marked out Scottish investment from 1178 in Arbroath Abbey, dedicated to Becket, as a humiliating act of penance. In this context St Thomas might simply have become a hate figure or alternatively a transparent propaganda tool for the Scots in their attempts to undo England's imposed feudal superiority in the eyes of the papacy and secular Europe.

However, William I was a prominent participant in and proponent of the AngloNorman cross-border culture of the day - noted by English chroniclers for his 'French' 
manners and preferences as king, just as he would later be celebrated for his genuine piety and humility. ${ }^{10}$ This Scottish king may, besides, have had private as well as public connections with Becket. The tale recorded by the thirteenth-century Chronicle of Melrose, that William and Becket had been schoolboy companions, may have been a later Scottish design to save face in the wake of 1174. Yet William's intense investment in his new Tironesian foundation at Arbroath, as a daughter of the Scottish border Abbey of Kelso, suggests a great depth of personal faith in the saint's powers as well as, perhaps, a genuine sense of penitence for his invasion. ${ }^{11}$ Arbroath quickly became Scotland's second-wealthiest monastic institution (behind St Andrews' Augustinian priory) and was undeniably to be the single largest new foundation in Becket's honour throughout Europe, a remarkable achievement for a realm as relatively poor as Scotland. The abbey was readily accepted into Scotland's growing national church network, receiving endowments from the nobility of Forfarshire and neighbouring Aberdeenshire and Fifeshire as well as successive Scottish and English kings. The abbey then formed strong associations with many of Scotland's other key religious foundations - both secular and regular. ${ }^{12}$

Not least, Arbroath's connection with Canterbury shared common ground with both Dunfermline Abbey and St Andrews priory cathedral, Fifeshire houses which had both been nurtured by the two most-celebrated royal patrons of Scottish monasticism, Queen/St Margaret (d.1093) and David I (1124-53): they had recruited monks from friendly archbishops of Canterbury for these Fife foundations. But Arbroath also shared common features with the border abbey of Melrose and Glasgow cathedral where Jocelin (d.1199), as Cistercian abbot then bishop at each in turn during William I's reign, developed his institutions and their buildings, cults and estates by consciously emulating 
the potent Canterbury/Becket model. ${ }^{13}$ Such adaptation of Canterbury's influence by the Scottish ecclesia would continue despite the ongoing role of that see's prelates as England's metropolitan, along with their counterparts at York and English royal backing, in continuing to claim English ecclesiastical jurisdiction over Scotland's clergy in the late twelfth- and thirteenth-centuries. ${ }^{14}$ It should be noted that much of William I's lavish endowment of Arbroath came only after Richard I of England's 'Quitclaim' charter, significantly issued at Canterbury itself on 5 December 1189, which released Scotland from the over-lordship terms of $1174 .{ }^{15}$ But the interest of Scotland's ruling dynasty and several leading noble families in Becket, Canterbury and Arbroath would be sustained thereafter despite - perhaps, really, because of - the deliberate cultivation after 1214 by the English Crown of Becket's cult and shrine as being of English national importance and thus of dynastic, political, economic and social value as well as a focus of universal faith. ${ }^{16}$ Scottish interest in Becket would continue, too, despite key moments of AngloScottish tension, notably the wars and near-wars of 1209, 1215-17, 1237 and 1244 and the awkward proposals of English over-lordship of 1251 and 1278, the latter incident taking place, again, at Canterbury itself where, according to John of Fordun's contemporary Scottish annals, Alexander III was present 'on a pilgrimage to St Thomas'. 17

Therefore, in this pre-1296 context, it is possible to understand a multiplicity of reasons for Scottish devotion to Canterbury and Becket, of 'divergent energies' at once private and public, local and national, spiritual and political, often seemingly contradictory but not mutually exclusive in the medieval world. ${ }^{18}$ A genuine sense of piety, hope, penance or gratitude may have occasioned both ordinary and elite Scots' pilgrimages and endowments to Becket, especially as St Thomas's reputation for medical 
cures grew. The record of at least thirteen Scots blessed by miracles at Becket's tomb in the late twelfth and early thirteenth centuries (including Robert, a servant of David, earl of Huntingdon (d. 1219), brother of William I), and the discovery of the aforementioned ampullae of Becket oil in excavations at Perth attest to the shrine's popularity with Scots despite the greater convenience of Arbroath. ${ }^{19}$

In the thirteenth-century, Scottish interest in Canterbury would have been spurred on, too, by the fame, visual power and guaranteed rewards of indulgences offered at the new shrine in which Archbishop Stephen Langton, attended by the young Henry III (brother-in-law of Scotland's Alexander II, future father-in-law of his son and heir, Alexander III) and many other foreign dignitaries, had St Thomas's remains installed on 7 July 1220, the first Jubilee year and Translation festival of the martyr. ${ }^{20}$ That year found Scottish lord Robert Bruce (IV) of Annandale (d.1245) and his wife (a daughter of David of Huntingdon) present at the Canterbury Translation of 7 July and making a grant of 1 Scottish merk per annum in perpetuity for themselves and their heirs to 'St Thomas, Martyr'. This was perhaps given to mark the birth of their first son, Robert (V), the future Bruce competitor for Scotland's kingship (d.1295): the gift was witnessed by Walter Stewart ('the Steward') and Alan, Lord of Galloway. ${ }^{21}$ The Bruces were also to be found about this time associated with further grants to the church of the Trinity, Canterbury, for 'God and St Thomas', including a similar sum from the lands of Cumnock in Renfrewshire, gifted by the lords of that region, the Stewarts, stewards of the kings of Scotland, who had founded a chapel to St Thomas in their Scottish holding. Tellingly, one of these grants was also witnessed by a 'Thomas, nephew of St Thomas', hinting strongly at some familial or tenure connection for the Bruce-Stewart kindreds with Canterbury. $^{22}$ 
In much the same way, kinship and personal piety (perhaps in the face of illness or fears of infertility) also saw Alexander II make pilgrimage to Canterbury in 1223: his first queen, Joanna, daughter of John I of England, was buried there in 1237, and his widowed French second wife was a pilgrim to Thomas in $1276 .^{23}$ The death of his English queen (1275) or his mother may also have been the reason behind Alexander III's gift of 100/- per annum about August 1279 to pay for thirteen paupers' meals to be distributed at Canterbury Christ Church every Tuesday (Becket's special day): this was a very public act of charity arranged for the king with Canterbury by the abbot and convent of Arbroath. $^{24}$

At the same time, however, all these acts of piety may have been motivated by far more complex factors than the simple search for a cure from disease or infirmity (with Becket's specialty emerging as leprosy), of for an indulgence, a blessing, a remission or the fulfilment of a vow of thanks which presumably brought many Scots south to Kent in this century. ${ }^{25}$ One thing the Scottish kings and the Bruces had in common was lordship of Midlands and south-eastern English lands. After the death in 1237 of John, earl of Chester and Huntingdon (nephew of William I and thus brother-in-law of Robert Bruce (IV)), the Bruces came into Essex holdings at Hatfield Regis, Writtle and Great Baddow, north of Kent. ${ }^{26}$ The Douglas family also held Essex lands at Stebbing and Woodham Ferrers at this time. Alexander Balliol of Cavers in Roxburghshire, Alexander III's Chancellor, was also lord of the barony of Chilham in Kent itself, along the Old Pilgrims' Way from Winchester and less than ten miles from Canterbury. ${ }^{27}$ Thus these Scottish landholders especially, but no less perhaps the many other Scottish nobles with northern English lands, would have found it natural as well as politic to establish ties of lordship and devotion with Canterbury in a world in which the archbishops of that great see so 
often played a vital role: for lords with more English lands than Scottish lands, like the Balliols of Barnard Castle (and of Galloway after 1233), this would have been even more the case. $^{28}$

For the kings of Scots, though, a political dimension to Canterbury or St Thomas observances can be taken further. Indeed, as Keith Stringer has noted, for William I and his bishops - and thus also for Alexanders II and III and their prelates - Becket could indeed serve as an increasingly potent icon of resistance to Plantagenet authority (although one they did not shirk from fighting against when required, for example sending Scottish lords in 1264-5 to aid Henry III against Simon de Montfort who had invoked Becket in his rebellion against the Crown). In addition, the papacy was open to strategic appeals to Becket's reputation and sacrifice in defending the rights of Mother Church and thus in the Scottish church's long-running jurisdictional fight against Canterbury and York as well as in an allied campaign for the rite of full coronation with unction for Scotland's kings. Despite a bull of recognition of Scotland's church as a 'special daughter' of Rome in 1192, just three years after Richard I's Canterbury 'Quitclaim' of overlordship, the papacy continued to be distracted by English claims to ecclesiastical superiority. ${ }^{29}$ St Thomas could be an invaluable association on many levels and the lessons and power of his life, martyrdom and miracles were adapted for differing audiences and politico-religious contexts throughout the realms of late medieval Europe: the Scots were thus surely similar to the French in invoking Becket in the course of tensions with England's Crown. ${ }^{30}$ Yet at the same time, such was the English Crown's veneration of Thomas - and with Edward I in the 1270s and 1280s this was especially true - that Scottish devotion and journeys to Becket and his tomb may equally have been 
deployed as a means of ingratiation with the Plantagenet House, facilitating talks over royal marriages, over-lordship and land issues. ${ }^{31}$

It must therefore be acknowledged that for Scots, too, 'it would be dangerous to assume that the complicated and ever-changing psychological and spiritual ramifications of St Thomas Becket's own cult can now be properly understood' ${ }^{32}$ It follows, then, that the potential ambivalence or versatility of what this saint, his shrine and their constructed image could stand for in the eyes of a non-English audience might have continued, or intensified, in its attractiveness to Scots even after a bitter national war broke out against England following the deaths of Alexander III and his grand-daughter, Margaret of Norway (1286-90), and the failed kingship of John Balliol/I (1292-96).

Admittedly, Becket's cult had a lot to live down in Scotland after 1296. Edward I, a regular pilgrim and generous patron to Canterbury throughout his reign, made significant public play of prayers and oblations to St Thomas alongside other English 'national' and local saints in the course of his military campaigns, as would Edward III (1327-77). ${ }^{33}$ Perhaps significantly, John Balliol was forced to submit to the English king c.7-10 July 1296 in a series of ritual humiliations staged at parish churches in Forfarshire which were within the hinterlands of the diocese of Brechin and Arbroath Abbey, a house at which Edward I surely observed St Thomas's Translation feast that year. The contemporary Lanercost chronicler certainly asserted of Balliol's surrender that 'by divine ordinance these things were accomplished on the morrow of the translation of St Thomas the Martyr, in retribution for the crime of Hugh de Moreville [Thomas's murder], from whom that witless creature [John] was descended' ${ }^{34}$ Then, in June 1297 , Edward I gifted some of the captured Scottish royal muniments to Becket's shrine at Canterbury. The saint's perceived part in Edward's triumph was then further marked 
when Balliol, passing through Dover (and surely Canterbury) about c. 7 July 1299, on his way to papal custody, was stripped of a spare crown and purse which were then gifted by Edward to St Thomas's tomb altar. Edward also observed Becket's feasts during the course of campaigns in Scotland in 1300 and 1303-4. ${ }^{35}$ A similar association for this English 'national' saint may have been deliberately cultivated by Edward when Robert Bruce (VII), earl of Carrick, the future rebel king of Scots, was obliged to submit to Plantagenet authority after his abortive rebellion at Irvine in Ayrshire in 1297 by swearing his loyalty - again c.7 July - on one of the swords used to kill Becket, a relic kept at Carlisle Cathedral, the border town where Bruce's father had been sheriff. ${ }^{36}$

Given the events of 1296-1304, Bruce and many other lords who would soon choose to be purely 'Scots' - as well as their common tenants - might easily have come to perceive Becket as an enemy icon and so made a clean break with Canterbury and its associated outposts, abandoning Thomas's cult in favour of dedication only to talismanic Scottish national and local saints and shrines, such as those of St Andrew, St Columba, St Ninian of Whithorn, or St Fillan of Perthshire. ${ }^{37}$ A similar history of English aggression in which Becket was among the icons invoked had certainly diluted Welsh association with the saint. ${ }^{38}$ Devotion by Scots to Becket might thus easily have become the refuge of exiled and disinherited lords in English pay, especially after Bruce's rebellion in 1306; the preserve of men such as John Macdougall of Argyll, who died while on pilgrimage to Canterbury in 1317, or the Strathbogies of Atholl, whose final heir's will was recorded at Canterbury c. $1373 .{ }^{39}$

Conversely, it might be contended that Robert Bruce (VII)'s symbolic Carlisle submission in 1297 was actually his own choice, a reflection of a strong personal and dynastic bond to St Thomas and his shrine and something to which many other Scots 
could still relate. Canterbury Cathedral Archive contains a Register copy of a letter from a 'Robert Bruce earl of Carrick' to Henry of Eastry, Prior of Trinity Church, Canterbury, from 1285 to 1331 and custodian of Becket's tomb. ${ }^{40}$ It is possible that this had been sent on behalf of an ailing Robert Bruce (VI), father of the future Scottish king, who was indeed earl of Carrick until his resignation of that title in 1293 but sometimes styled thus in English administrative documents, particularly after he retired to his Essex estates, between $c .1298$ and his death about the time of Scottish re-capitulation to Edward I in 1304 (he was also lord of Annandale, 1295-1304). ${ }^{41}$ However, the letter may alternatively represent the wishes of Robert Bruce (VII), the king-to-be, who was also styled as earl of Carrick by English documents within this period and did legally hold this title 1293$1306 .^{42}$ Indeed, the content of the letter to Prior Henry points more temptingly to the younger Bruce and could be aligned with his oath at Carlisle in 1297, calling as it does for the prior and convent to take custody of two gold rings enclosed with the letter and to place one on the altar of St Thomas and the other on a pillar nearby. This was, perhaps, an offering given on behalf of 'our estate', as it is stated, at the time of Bruce (VII)'s second marriage, to Elizabeth de Burgh, daughter of the earl of Ulster, shortly after his return to Edward I's peace in early $1302 .{ }^{43}$ The letter is certainly further proof of a close Bruce family relationship with Canterbury and St Thomas, one which would have struck a chord with Edward I but building on the links first established by the Bruces between 1178 and the Jubilee year of 1220: Prior Henry is addressed with familiarity and affection as 'his dear friend' and is urged to find a prominent place for the rings amongst the sender's other 'offerings' (plural), 'if God Please'. Robert (VII)'s sister, Mary, and daughter, Marjorie, may have acted upon this family link c.1306-15 by visiting Canterbury when they were in custody at Rochester which was itself the site of a shrine 
to a Scottish pilgrim slain en route to Canterbury in 1201, William, a baker of Perth, canonised in $1256 .^{44}$

If the Bruce letter to Henry of Eastry was sent by the future king of Scots this was arguably the second of several Becket associations for Robert (VII) in the years before his seizure of the Scottish throne. This was a path which would be shaped by severe physical and psychological tests in which the would-be king must have called upon and rationalised from very deep reserves, both of expediency and faith. On 10 February 1306, of course, Bruce's campaign was precipitated violently into action through his murder of John Comyn of Badenoch. That the Franciscan friary at Dumfries where this crime was committed also lay close to a chapel to 'St Thomas Martyr' would not have escaped Bruce, just as his own act of sacrilegious murder may have bound him even more emotionally to observing Becket's cult. ${ }^{45}$ But it may have been Bruce's at once opportunistic yet heartfelt, earnest interpretation of another significant event which determined that as king he would display a firm level of personal as well as politic commitment to St Thomas alongside other royal and regional saints: that is, on 7 July 1307, the Translation feast of Becket, when Edward I died at Burgh-on-Sands, a few miles short of re-invading Scotland. ${ }^{46}$

Over and above this 'sign' for the Scots, Robert I - now physically cut off from Canterbury - had many other strong reasons after 1306 to develop an important relationship with Scotland's Becket centre, Arbroath Abbey. The resources of this, one of the wealthiest monastic houses of the realm and one recovered from English occupation relatively early, c.1308-09, made it a desirable base for the Bruce regime's chancery. In Abbot Bernard of Arbroath as Chancellor, Bruce employed an extremely skilful bureaucrat and propagandist, one of a crowded bench of determined Scottish churchmen 
who, if Robert was not already aware of the full canon of Scottish royal and ecclesiastical icons and sites, would have impressed upon their king the value of association with just such a spiritual regiment. ${ }^{47}$

Tentative extrapolation from Robert I's extant acts permits the inference that he was aware of and probably observed each year in some form not only the Translation (7 July) and Martyrdom (29 December) feast days of St Thomas, but also the 'regressio de exilio' feast of 2 December, a red-letter day shared uniquely, as Keith Stringer has shown, by Canterbury and Arbroath (the 'return from exile', apt given Bruce's flight to the west in the winter of 1306-7). ${ }^{48}$ Admittedly, Robert I's presence cannot be unquestionably confirmed at Arbroath Abbey about the time of the Martyrdom feast for any year other than 1315, although in October that year Robert did pay for candles to be kept lit at the tomb of the abbey's founder, William I. ${ }^{49}$ Much of Robert's largesse to Arbroath may have facilitated rebuilding work ongoing there in the wake of a serious fire in 1272 and, as G.S. Gimson has shown, this may have included a new funeral effigy of King William, in Frosterley marble from Durham, commissioned c.1315-29. ${ }^{50}$

Nevertheless, despite these gifts, Bruce did not choose to visit Scotland's chief Becket site in the last weeks of his life, travelling instead to St Ninian's at Whithorn in Galloway in spring 1329 and ordering that his own remains be interred at Dunfermline in Fife and Melrose in the Borders. This would seem to suggest that Robert's interest in Becket had become increasingly political and strategic after 1306-07. Such a shift was understandable. The Crown's favour to Arbroath's co-patrons of St Thomas and the Virgin Mary would have allowed Robert to identify his regime with a host of valuable spiritual figures for his cause. In acting thus his model was surely Edward I, a king well able to fulfil the royal need to associate with, and therefore link in the minds of his 
subjects and enemies, an eclectic host of both national and regional saints and shrines, turning personal public observance in the service of his court, policies and wars. ${ }^{51}$

Therefore, in theory, for Bruce and his supporters, the large almonry chapel of Arbroath Abbey - a building detached from the convent there and suggesting a continued strength in pilgrim numbers to the Angus house - and which was dedicated to St Michael, might be associated with the dedication to that archangel of the chapel at the strategically vital Stirling Castle (the Chapel Royal from 1501). Similarly, the hospital at Arbroath was dedicated to St John the Baptist, whose town of Perth (St Johnston) Bruce led his troops to liberate in 1313 and whose feast day after 1314 would become the anniversary of the battle Bannockburn (24 June) at Stirling, another date which Bruce and his subjects are likely to have observed annually. ${ }^{52}$

These are minor associations but there is no doubting the greater potency of the presence in the care of the abbots of Arbroath - since a grant of William I - of the Breccbennach, a reliquary, originally held at Dunkeld, of St Columba (521-97), the father figure of Scotland's Christian Church (feast day 9 June). It is this relic which Robert is held traditionally to have used to inspire his host at Bannockburn in 1314, an army to which the king's speech before the battle is also significantly recorded in a contemporary verse, attributed to Abbot Bernard of Arbroath, as invoking: 'John the Baptist... and St Andrew and St Thomas who shed his blood along with the Saints of the Scottish Fatherland [and] will fight today for the honour of the people, with Christ the Lord in the van'. ${ }^{53}$ Given the history of Bruce links with Becket's cult detailed above, this saint and Arbroath should surely now be given greater prominence in the Bruce wars against England. 
Some of the 'relics' (plural) of St Thomas, recorded in Arbroath's care as late as 1517, may also have been borne on Scottish military campaigns $c .1308-57 .{ }^{54}$ Little wonder, then, that Arbroath abbey - still surely in the process of rebuilding after a fire in 1272 - was to receive the greatest number of grants from Robert I of all Scotland's monastic foundations. ${ }^{55}$ This included numerous confirmations and inspections of its original charters of regality privilege from William I and Alexander II, exemption from prise and tolls, some extra lands and churches and the right to use a cocket seal for trade like a royal burgh. ${ }^{56}$ Arbroath Abbey's trade rights were perhaps extended in compensation for its lost exemption from customs toll in all ports in England (originally granted by Henry II). Lastly, in 1328, Robert certainly attempted to persuade Edward III to regrant Haltwhistle church in Tynedale to Arbroath Abbey, a gift first made by the Bruce family to the abbey in honour of St Thomas as early as $c .1178-80$. The latter suggests that the restoration of such cross-border tenurial and spiritual links may have been considered by Robert I as a means of cementing the Anglo-Scottish peace treaty of 1328 but quickly abandoned. ${ }^{57}$

Beyond Forfarshire, however, St Thomas's other Scottish connections afforded Bruce with further powerful tools of association and persuasion before 1328. Glasgow's Cathedral shrine of the tomb of St Kentigern (visited by Edward I in 1301) preserved 'in a square silver coffer' parts of the 'Loricae' [shirts] of Becket and Kentigern (feast 13 January), as well as 'a precious burse with combs' of both saints: these were presumably to be found on an altar to St Thomas in Glasgow cathedral nave. The cathedral also oversaw two chapels dedicated to St Thomas on Glasgow's outskirts and its Registrum contained written materials about Becket's life, martyrdom and miracles. ${ }^{58}$ As A.A.M. Duncan has shown, the role of Jocelin, former abbot of Melrose and bishop of Glasgow 
(1175-99), in emulating the contemporary development of Becket's cathedral body cult (and investigating Scottish Becket miracles for William I) may explain the establishment of a Translation date for St Kentigern of 6 July, the eve of that of St Thomas's Translation. ${ }^{59}$ A grant of 20 October 1321 by Robert I, of the church of St Kentigern at Kirkmahoe, Dumfriesshire, to Arbroath Abbey suggests that the king was aware of this Kentigern-Thomas link. ${ }^{60}$ If so, it is perhaps easier to understand why Robert also made such a display on 5 July 1318 in attending the consecration of the finally completed St Andrews cathedral. ${ }^{61}$ This was a lavish public ceremony which also potentially established a run of three major feasts or 'national' liturgical days to be observed by the Scottish establishment and with associated sermons and indulgences: that is, 5-6-7 July St Andrew's consecration, then the Translations of Kentigern and Thomas - all falling in a fortnight which also included the Visitation feast of the Virgin (2 July), the feasts (2930 June) and Octave of Apostles Peter and Paul, the death date of Alexander II (8 July), Robert I's own birthday (11 July) and the inauguration of Alexander III (13 July). ${ }^{62}$ The king and his court may have travelled from St Andrews to Arbroath c.5-7 July in the crisis year of 1318 thus perhaps explaining why the contemporary verse which records the king's aforementioned Bannockburn speech (preserved in a fifteenth-century chronicle manuscript) invokes Andrew and Thomas in the same breath. A reliquary of St Andrew might also have been brought to the 1314 battleground, as well as a relic of $\mathrm{St}$ Fillan (feast 9 January), a key Perthshire cult which had been invoked by Bruce as he escaped into exile in 1306. Significantly, all these feasts may have been very publicly marked in 1318, a year in which the English Crown and prelates had made great play of the papacy's re-excommunication of Bruce and the threat of interdict upon Scotland. ${ }^{63}$ 
These were spiritual associations which Bishops Wishart of Glasgow and Lamberton of St Andrews and Abbot Bernard could all too easily impress upon a king who had so badly needed their approval and guidance in 1306 and from whom they would have extracted an oath to the Church.$^{64}$ Less obvious but by no means less persuasive spiritual associations may also have been used to win the hearts and minds of Bruce's opponents in Fife and Galloway. At Dunfermline Abbey, the body shrine of St Margaret of $c .1250$ (feast day 16 November, translation feast 19 June) and the links there of her late eleventh-century foundation of Benedictine monks from Canterbury were a further boost to Robert's association with his MacMalcolm predecessors' royal mausoleum at this Fife monastic site.$^{65}$ Similarly, the cathedral body shrine of St Ninian at Whithorn in Galloway (feast day 26 August, translation feast 31 August), in a church dedicated to the French realm's favourite saint, Martin (feast day 11 November, translation feast 4 July), may have provided another link to Becket's shrine city: the earliest British Isles churches dedicated to St Martin were held to have been in Canterbury and Whithorn. ${ }^{66}$ As with the several feasts of St Thomas, the key liturgical days of these holy figures may have been observed by Robert I either when the itinerary of his campaigns and diplomacy permitted or around the daily routine of his household and chancery.

In this context, St Thomas formed an important standard or weapon with which Robert and his regime could combat and/or persuade his opponents and potential allies. It can easily be imagined that the Scottish clergy - in the same vein as the Bannockburn address - invoked this network of saints in the preaching to their flock which English captains in Scotland so feared. ${ }^{67}$ Arguably, this was a natural war-time reflection of established saintly inter-connections which had informed worshipers and pilgrims in 
Scotland for centuries past of valuable journeys and devotions which they might make throughout Scotland and beyond their realm to shrines associated with their own local cults. As Diana Webb has shown, a pilgrim to one shrine had often already gone to another, usually local, religious site and perhaps failed to secure a cure there, and/or had a vision urging them to journey on to another, more potent, saint's relic or tomb, or even pre-planned a journey to several connected shrines, depending upon the severity of their infirmity, guilt or piety: in such practice Becket was often to be found as a partner to other saints and their shrines. ${ }^{68}$

Robert I's regime clearly continued to show an interest in Thomas's cult and its political as well as spiritual value, particularly in dealings with the papacy: the 'Irish Remonstrance' of 1317, issued by Irish supporters of the Bruce invasion of 1315-18, invoked Becket's cause against the English Crown as if 'for justice and the defence of the church'. In the same way the Scots may logically have ensured that the bearers of the Scottish nobles' letter to John XXII sealed in April 1320 - now known as the 'Declaration of Arbroath' - prefaced its delivery by invoking the Canterbury martyr. ${ }^{69}$ In addition, Bruce's regime must have taken comfort from the failure $c .1324$ of Edward II's campaign to secure papal permission to include anointment with the 'Holy Oil of Becket' - held to have been given to the Archbishop by the Virgin to be later rediscovered thus allowing its royal user to recover lost lands to the English Crown. This was a prophecy of which Robert I must have been aware: the Scots, of course, secured their own rite of unction for coronation from the papacy in $1329 .^{70}$

However, during prolonged and destructive warfare and diplomatic tensions, although religious observance might become more intense, local worship must survive and grow first at a time when travel was exceptionally dangerous and resources scarce. 
There is some evidence, indeed, that Robert I's personal and strategic devotion to St Thomas effectively persuaded his subjects to favour the cult closer to home. In 1317, the Bruce king confirmed a grant by the Gaelic earl of Lennox, transferring an annual of four oxen from Cambuskenneth's Augustinian priory of St Mary to Arbroath Abbey. ${ }^{71}$ Then, on 4 September 1327, Sir David Lindsay of Crawford confirmed a grant of lands to a chapel of 'St Thomas, Martyr', adjacent to Crawford castle in Lanarkshire. ${ }^{72}$ Finally, on 16 May 1328, Bruce's most trusted lieutenant, Thomas Randolph earl of Moray (Guardian 1329-32), endowed no less than five perpetual chaplainries, at $£ 23$ 13/- 4d annually, in the name of St Thomas at Elgin Cathedral in Moray for the soul of 'our magnificent prince and lord, Robert, by grace of God King of Scots, our illustrious uncle'. This last grant is a clear indication of a continuing and perhaps intensifying close link between the ruling Scottish houses and Becket's cult during the wars. ${ }^{73}$

However, there is no extant proof that, once Anglo-Scottish peace was concluded in 1328, significant Scots began to seek safe-conducts from Edward III to make pilgrimage to Canterbury and Becket's tomb itself, although Robert's leading general, Sir James Douglas, charged with taking his king's heart to the Holy Land after death in 1329-30, may have passed through England and thus Canterbury en route to the continent. ${ }^{74}$ For the Scots, Arbroath and Becket associations had been a clear asset in war against England, not a 'liability' but despite the peace treaty of 1328, Anglo-Scottish relations may have remained too tense, Bruce's recent invocations of St Thomas too adversarial and Canterbury just too far for an immediate resumption of Scottish pilgrimage traffic to the chief site of this cult. An uneasy truce, Bruce's excommunication and a (failed) regicide plot had denied any Scots the chance to participate in the Jubilee feast at Canterbury in 1320 and war would quickly resume in 1332: there are no extant 
safe-conducts for Scottish pilgrims to Canterbury for the twenty-five years after Robert's death. $^{75}$

In all that time the English Crown arguably gave the Scots further cause to sever devotional links with Canterbury and Becket. Edward III, like his grandfather, would be an annual visitor to Canterbury, Becket's tomb and the other altars of the cathedral and monastic sites there as well as making frequent use of St Thomas and England's other chief shrine saints in his war-propaganda against Scotland and France. ${ }^{76}$ But far from abandoning Becket observances, Robert I's son and successor, David II, seemed destined to emulate his father's at once personal and political promotion of St Thomas in the face of English aggression. David's seven-year refuge in France (1334-41), a period which mirrored Becket's own exile, must have increased his awareness of the anti-English value of this saint. The diocese of Rouen in Normandy, where David stayed at Château Gaillard, boasted almost sixty Becket dedications, including Henry II's priory in Rouen itself. ${ }^{77}$ David's first stop after his return to Scotland in June 1341 was at Arbroath to confirm the regality status granted to the abbey by William I. Thus St Thomas might easily have been among the arsenal of figures and relics invoked and borne by David's host in his campaigns against England c.1341-6. ${ }^{78}$

But David's capture in battle in October 1346 and the eleven years he would spend in captivity in and around London would cause a marked shift in the Scottish Crown's attitude to and promotion of St Thomas and Canterbury. A more anglophile approach to that city and its chief cult may already have been introduced to David through the personal and public faith of his English wife, Joan of the Tower, Edward III's sister. ${ }^{79}$ Yet it was surely David's observation at first hand of the importance of the cult to Edward III and his subjects, as well as to England's other wartime prisoners, which 
was most influential. David may have been aware of Edward's annual feast visits to Canterbury as well as to other shrines but also of the English king's gift of a golden ship to Becket's altar while at Canterbury in 1343 and a further $£ 40$ statue of gold in 1353. The Scottish king would have had even more chance of hearing of the pilgrimages on parole of Edward's various French prisoners, including those given as collateral for Jean II after his capture at Poitiers in 1356: Jean himself, another exile, made several pilgrimages to Canterbury and had his heart interred there in $1364 .{ }^{80}$

However, David's motives for developing his own and subsequently his realm's association with Becket and Canterbury, and of signalling this activity to Edward III, surely went beyond an immediate diplomatic and personal need for a treaty of release. David did arrange through the English Chancellor to secure Edward's permission to make a pilgrimage to Canterbury from London on horseback between 10 and 12 September 1357, the week before his final liberation. David explained the reasons for wishing to make such a pilgrimage as likely to be greatly pleasing to himself and his guardian (Sir William Trussell). Yet this probably spoke more to the recurrent illness which David faced because of his battle wounds rather than any perceived need to sweeten the English king and community to release terms (which had already been decided). David is recorded as giving an oblation of $18 \mathrm{~d}$, presumably to Becket's altar, as well as $16 \mathrm{~d}$ in alms on this trip which cost his keeper $£ 71$ 13/- 4d in total: David was also attended about that time by Edward III's physician, a Jordan of Canterbury. ${ }^{81}$

This was the first in a number of personal acts of patronage by David associated with Canterbury which suggest that he was acting, at this juncture, out of sincere piety, not merely convention or political expediency: numerous factors including his captivity, his domestic political predicament, his apparent infertility, recurrent illness and the 
backdrop of plague epidemics after 1348-9, may have precipitated such a spiritual shift. In its grip, David seems to have revived Alexander III's commitment of the Scottish Crown of 1279 to provide alms for the poor at Becket's shrine: in 1359 Scotland's Exchequer Rolls record the payment of some £7 10/- of 'Canterbury Alms' from the accounts of the sheriff of Forfarshire, indicating the levy of this sum from Arbroath's hinterland ${ }^{82}$ David may have intended to pay these alms or make public oblations in the course of further personal visits to Canterbury using gold noble coins, a regular royal use of such high-status specie at this time. The Scottish nobles were modelled on Edward III's issue of 1351 which David's Florentine minters in Edinburgh produced after $c .1357$ in very small numbers and to the value of 6/- 8 d, roughly equivalent to Edward I's standard 7/- donation coins. ${ }^{83}$ But much more significantly, in 1358, the king may have had a hand in a written request from the abbot of Arbroath to Canterbury for an additional relic of St Thomas for the Scottish house ${ }^{84}$ At the same time, David certainly patronised one Richard Ellisworth, an English clergymen paid as a royal chaplain in 1359: the king petitioned the papacy on 27 June 1358 to award Ellisworth a benefice within the diocese of Canterbury. ${ }^{85}$

Whether or not David sought to favour a Canterbury cleric in the manner of his father's or grandfather's request to Prior Henry of Eastry, or if David had simply met Ellisworth in the course of his pilgrimage in 1357, the king would have several subsequent opportunities to build on his relations with the Kent cathedral. Indeed, in all, after his release David made five explicit requests for safe-conducts to visit the tomb of St Thomas at Canterbury. These were granted on 20 August 1364 to David and his second Queen, Margaret Logie, with a retinue of thirty until 2 February 1365 (taking in the Martyrdom feast); on 6 November 1364 to David alone with thirty followers until 29 
September 1365 (taking in the Translation); on 20 May 1365, repeating the previous permit; on 18 March 1366 for David, Margaret and Patrick Dunbar, earl of March, with a combined retinue of one hundred and twelve until Christmas (David's grant was repeated on 15 October); and on 4 January 1368 to David and Margaret and a hundred followers until Easter. ${ }^{86}$ In addition, David requested conducts to visit other shrines such as Our Lady at Walsingham on a number of occasions as well as receiving numerous safeconducts to enter England on general un-stated 'business', presumably diplomatic talks at London, which might have allowed him to journey on over three-to-six days to Canterbury and back (as he had done in 1357) or at least to pay for a proxy pilgrim or oblation to Becket. David is known to have made at least four journeys to London in person with retinue - in late 1358, late 1363, and about May of each of 1365 and $1369 .{ }^{87}$ This larger general list of travel requests also includes a permit granted on 28 February 1370 for David and a retinue of forty which would have allowed the king to attend the Jubilee Translation feast at Canterbury that year: the gap in David's extant acts (31 May to 15 July), the issue of his privy seal letters delaying the next ransom instalment (dated at London on 4 June 1370) and his large expense on talks with England that year, some $£ 966)$ suggests that he may indeed have gone to Canterbury in person, a visit not previously noticed by historians, at a time when he already knew his health to be failing (and he also badly needed clerical support to secure an annulment of his marriage to Margaret). ${ }^{88}$

Although it cannot be verified if David used all these safe-conducts, if it was his aim to lead by example after his release and to encourage his subjects to resume pilgrimage to Canterbury he was successful. Between 1357 and 1406 the English Crown issued safe-conducts to some thirty named individual Scots seeking explicit permission to 
visit St Thomas's shrine at Canterbury: a number of these Scots made repeated requests and, perhaps, visits with retinues ranging in size from four to twenty or even thirty men on average. ${ }^{89}$ But this sample increases drastically (by perhaps as much as a factor of ten) when it includes the names, too numerous to list fully, of those Scots issued permits to enter England on a general pilgrimage to a number of unidentified English shrines or granted passage through England on pilgrimage to shrines or other business in "parts overseas', presumably very often travelling via the Dover Road and thus Canterbury. To these hundreds of Scots (if their retinues are included), many more unknown Scots might be added - those of a lower class travelling without permits and all those taking ship directly to the Sussex, Kent or East-Anglian ports. ${ }^{90}$

Within the larger named samples, however, a variety of the many motivations of the typical pilgrim can be glimpsed. There were those Scots travelling in search of a cure, in anticipation of their own death or, perhaps, as part of the obsequies of a family member, activities which must have multiplied in what was an age of recurrent plague (1348-50, 1361-2, 1380). For example, Patrick Dunbar, earl of March received at least six safe-conducts, with retinues ranging from eight to twenty men, from 1358 until his death aged about eighty-five in 1368: a permit of early 1362 may have been granted to allow the earl to mark the death of his son and heir, John, in captivity in England, possibly of the plague. ${ }^{91}$ Similarly, the large group of Scots headed by March, William earl of Douglas and Thomas earl of Mar may have sought passage explicitly to Canterbury in November 1362 as part of the funerary tributes of Queen Joan (d. 7 September 1362), estranged from David II since 1358 (and March's cousin), or of Thomas Stewart, earl of Angus (who had died of the plague in a Scottish prison c.1362). And of course David's wounds always seemed to need curing throughout his last decade of life. ${ }^{92}$ 
There were also those Scottish pilgrims to Canterbury whose purpose may have been to ease their own period of captivity or to absolve transgressions against Edward III committed during truce: for example, Sir Hugh Eglintoun, Sir John Towers and Sir Archibald Douglas, granted general safe-conducts in 1357, 1358 and 1359 and who had been captured both at Poitiers and then during a border raid in 1358; or Robert of Caithness, valet of William earl of Sutherland, a hostage prisoner for David in $1362 .{ }^{93}$

Then there were those acting out of contrition or fulfilling a penance perhaps imposed by the Scottish Crown: for example, Sir John Kennedy of Dunure in Ayrshire, guilty of slaying a priest said to have slandered him to King David, who was permitted on 10 October 1363 to travel to St Thomas's tomb at Canterbury and then on to France; or Alexander Stewart, fourth son of Robert II (1371-90), imprisoned by David II for failure to impose order on his Badenoch tenants in northern Scotland and granted permission on 26 August 1374 to make pilgrimage in England with, remarkably, Sir Walter Leslie, his feud enemy for the earldom of Ross. ${ }^{94}$

Finally, there were many Scots who might be said to have planned a pilgrimage out of pure devotion, no other stated or detectable reason surviving to explain their decision. A number of these Scots sought safe-conducts as individuals with retinue and seemed to seek passage repeatedly throughout their own lifetime hinting at a commitment to Becket's shrine as a firm plank of their personal faith. For example, Thomas and Gilbert Macolagh (MacCulloch), minor Galloway nobles in English allegiance before 1350, sought permits to Thomas's shrine in 1358 and 1360; Sir Thomas Somerville applied to go to his namesake's shrine at Canterbury in 1362, 1363, 1364 and 1369; and Eleanor Douglas, the many-times widowed Countess of Carrick sought to enter England 
to visit 'the shrines of the saints' in 1358 and specifically Becket's tomb in 1373 and $1375^{95}$

But quite strikingly there were also large numbers of Scots who either applied for or were granted permission to travel into England and often on to Canterbury seemingly as a group. It may be that such listed names sought to take safety in numbers on their journey but even if they nonetheless travelled alone, their simultaneous permit and shared destination suggests that they may have been motivated either by shared vows borne of a common role back in Scotland in a religious endowment, the birth or death of a notable individual or the collective goal of participation in a (very often, once-in-a-lifetime) longdistance adventure beyond Canterbury and England's shores. Such a group can be found receiving permission to travel through England on their way to St John the Baptist's tomb at Amiens on 16 October 1365, presumably via the Dover road and Canterbury, and featured nineteen named Scots with over ninety followers. ${ }^{96}$ This group included some important laymen, namely Sir Archibald Douglas, Sir Alexander Lindsay of Glenesk, Sir Robert Maxwell, esquire Alexander Recklington and what seem to be a number of nobles' sons, such as Duncan Fleming, John Weymss and Nicholas Erskine; but it also contained churchmen - John abbot of Dunfermline, David de Mar treasurer of Moray and Preceptor of the Scottish Knights Hospitaller and John Barbour archdeacon of Aberdeen (later author of The Bruce, the celebrated verse chronicle of Robert I's reign).

However, the fact that many of these individuals would be named on a number of such permits from Edward III between 1358 and 1371 suggests that some of the pilgrimage safe-conduct evidence from this period - especially, it should be noted, the roughly $90 \%$ of passes issued where Canterbury was not the explicit destination - actually 
represents hopeful, or even in some cases coercive, Crown-sponsored pilgrimage to England, engineered by David II and his close supporters. To take one obvious example, about 5-6 December 1363, some thirty-nine named Scots with over two hundred followers, in four groups of varying size and some as individuals, were issued with permits to cross the border either on 'pilgrimage in England' or on unstated business. These documents were, though, issued exactly at a time when David II was actually in England with Edward III drawing up fresh plans for a peace treaty which included the prospect of an English prince being admitted to David's royal succession ahead of his heirs presumptive, the Stewarts, as well as the restoration of the Scottish lands of some of the exiled lords disinherited by Robert I. ${ }^{97}$ In this context, these collective travel permits may rather have been sought by David and his councillors and issued in an attempt to expose as many influential Scots as possible to a positive experience in England at Edward III's court and/or Canterbury and thus to persuade them to further accept David's diplomatic plans of closer relations with their former enemy: to socialise Scots, in a sense, within the English 'communitas' ${ }^{98}$ There thus remained a distinct political dimension to the Bruce dynasty's desire to encourage their subjects in devotion to the cult of St Thomas: where Robert I's interest in association with Becket c.1306-29 had been antagonistic in its stance towards England, David II now pushed a pro-English, antiStewart agenda. ${ }^{99}$

Allied to this, David actively sought in person a general safe-conduct for Scottish students to study at Oxford or Cambridge Universities after 1357 (a permit significantly also renewed on 5 December 1363). Ninety Scottish clerics had received permission to do so by 1400 , many of them clerks for David's government: these men represent another group who could also have gone to Canterbury unnoticed. ${ }^{100}$ Similarly, David secured a 
general safe conduct for Scottish merchants to enter England, which they did in scores after 1357, members of a highly influential estate now admitted to Scottish parliaments who could also undertake spiritual activity: a John Goldsmith, bailie of Edinburgh, certainly secured passage to St Thomas's shrine at Canterbury in July 1358; Edinburgh super-merchant, Roger Hogg, also secured permission for pilgrimage to St James at Compostella through England with his wife in $1362 .{ }^{101}$ At the same time, the second Bruce king was a celebrated and determined patron of eastern Scottish Lowland men of chivalry interested in participation in crusades to Prussia and the Holy Land: men such as the Leslies, Lindsays, Hepburns, Barclays, Abernethys, Edmonstones, and Erskines who featured regularly on passes on pilgrimage or through England to parts 'overseas' and, again, may have reached Dover via Canterbury. ${ }^{102}$

The exact mechanism by which Scots obtained travel permits from the English Crown is unclear: we do not know whether individuals had to approach the Scottish Crown first, securing the permission of the King and Chamberlain who would then approach the southern kingdom's officials, or whether Scots could make independent requests direct to England. ${ }^{103}$ But if David and his ministers were, in any case, soliciting pilgrimage passes to Canterbury and elsewhere for some Scottish subjects and pressurising them to go it is highly likely that many such permits were never used. This would have especially been the case where David targeted greater nobles whom he regarded either as disaffected or as potentially valuable political allies but in need of further Anglophile persuasion or coercion. Thus the many safe-conducts to Canterbury and elsewhere issued and often repeated to William, earl of Douglas, and Patrick Dunbar, earl of March, might easily include passports which were never taken up. ${ }^{104}$ Similarly, at moments of political crisis in Scotland David may have sought to dilute some of the 
factional opposition to his diplomatic and territorial agenda by seeking to send men like Douglas and March - who joined Robert the Steward of Scotland and his sons in coercing David in Spring 1359 and in openly rebelling against the monarch in Spring 1363 - out of the kingdom ostensibly on pilgrimage. For example, in November 1362, in the wake of David's siege of Kildrummy castle in Aberdeenshire and the forfeiture of its owner, Thomas, earl of Mar, a pass to Canterbury was issued to the earl of Douglas (Mar's brother-in-law), the earl of March, the bishop of St Andrews and Mar himself. The latter was a maverick who might have been drawn to adhere to David's plans for a military alliance with England if his becoming a liege man of Edward III while in ostensible exile from Scotland after 1362 could be combined with regular pilgrimage to Canterbury. ${ }^{105}$

The departure of these magnates from Scotland - as with all other pilgrims and crusaders - would have seen their lands and goods placed under the protection of the Crown and they could have had no input to daily patronage, council or parliament at sensitive moments. That David monitored pilgrimage activity with this in mind is illustrated by Edward III's 'revocation' on 20 April 1363, cancelling Patrick earl of March's safe-conduct to St Thomas's tomb at Canterbury at the height of the aforementioned earls' rebellion (including March) against the Scottish king: David must have informed the English officials who would not harbour rebels against the Scottish monarch. ${ }^{106}$ By the same token, of course, requesting passage to Canterbury might also be a ploy used by these same magnates themselves to safe-guard an escape route away from David. However, such a Crown policy could only be effective where there was genuine interest in such a long-distance pilgrimage and Thomas's cult. The further pilgrimage passes to Canterbury issued to other Douglases and March's successors 
c.1371-1400 suggest that these houses of Anglo-Norman stock were the most consistently open to the possibility of closer political, social, economic and cultural relations with England, despite their dominance of border warfare. ${ }^{107}$ By contrast, those nobles who clashed most regularly with David's regime and plans in the 1360 s and whose political and spiritual outlook might be said to be predominantly Gaelicised - Robert Steward as earl of Strathearn and Atholl, or William, earl of Ross - never received any sort of pass to England.

A significant proportion, therefore, of all the recorded Scots given permission to visit Canterbury by Edward III, or to enter and/or pass through England for general pilgrimage or continental devotions, holy warfare and peacetime business, were not motivated by purely spiritual interest in St Thomas's relics and shrine. This is a pattern of motivation similar to that of pre-1296 Scots but the Becket devotions of the Scottish elite at Canterbury in the later fourteenth-century were, nonetheless, arguably often more complex in their motivation than, say, their counterparts in France, Flanders and other European realms and were affected more directly by personal and political concerns in their home realm. This was a development determined partly by the relative ease of access of Scots to their southern neighbour during truces, but far more by the unique diplomatic and domestic circumstances of David II's reign after his capture in 1346.

However, even though David related to St Thomas in a different way than had his father, his reign nonetheless underlines the necessity of the support of an active king of Scots to encourage Scottish subjects' participation in such contact with England if it was to occur and flourish. In that sense David's crucial personal interest in Becket and Canterbury, and his procurement of general passes for Scottish nobles, merchants and students, too, was highly influential. Still, the large numbers of extant passports to 
Canterbury or England of c.1357 to 1371 may be proof that David's efforts in reality only gave further impetus to a universally popular devotional path which would have revived and grown in some measure anyway and of which the fame and pulling power to Scots had survived over sixty years of Anglo-Scottish war, sustained by plague, economic hardship and the potentia of the martyr. The abbot of Arbroath's aforementioned letter to Canterbury in 1358 requesting a relic of St Thomas perhaps sought to supply an existing demand rather than create or revive one: the contemporary vernacular source for the late fourteenth-century used in the verse chronicle of Andrew Wyntoun, prior of St Serf's at Lochleven in Fife (c.1408-24), certainly asserted that: 'Off him [St Thomas] the fest is haldin ay' in Scotland. ${ }^{108}$

This may explain why, contrary to the general assumption of historians, the numbers of Scottish pilgrims to Canterbury and St Thomas did not in fact collapse abruptly after David's death in February 1371 and the coronation of his political antagonist, Robert Steward/Robert II (1371-90), as the head of a Stewart dynasty which was established in western, central and northern - largely Gaelic - Scotland. True, the number of significant Scots seeking passage explicitly to Canterbury and Becket's shrine did dwindle over the period 1371-c.1404 and this may reflect a loss of Crown and noble interest: only a dozen or so Scots received such passes. ${ }^{109}$ A number of factors must have reduced Scottish activity in England and at Canterbury especially. After Edward III's death in 1377 Anglo-Scottish border conflict did resume, punctuated by a joint FrancoScottish expedition in 1385, Richard II's burning of south-east Scotland in the same year, the Scottish victory in battle at Otterburn in 1388, Henry IV's invasion to Edinburgh in 1400 and Scottish defeat at Humbleton in $1402 .^{110}$ The Peasants' Revolt in 1381 and the Lancastrian coup of 1399 may also have discouraged Scots from visiting southern 
England. ${ }^{111}$ In addition, both Richard II and Henry IV took fresh interest in the old legend of Becket's Holy Oil as adding to England's royal rite of unction and a claim to fulfil the prophecy of re-conquering lost lands. ${ }^{12}$ More importantly, though, English and Scottish support of rival popes during the Great Schism of 1378-1418 may have hindered Scots' travel south. ${ }^{113}$ Finally, the burial of Edward the Black Prince, a devotee of the Trinity cult, in Canterbury in October 1376 close to the high altar and Becket's shrine, may also have deterred noble Scottish visitors to what was thus even more so a Plantagenet spiritual home: notably, the Douglas family sent several members to St Thomas at Canterbury after 1371, but these explicitly-stated travel requests did not re-occur after June $1375 .^{114}$

However, the number of Scots issued safe-conducts to enter or pass through England for other purposes - English counties, continental or Holy Land pilgrimage, tournaments, papal, diplomatic or mercantile business - remained remarkably buoyant $c .1371-c .1400$ and took advantage of the numerous periods of truce. ${ }^{115}$ Many of these individuals could have included Canterbury in their itinerary. For example, the twelve Scottish knights - members of David's court and officer class - who secured passage through England for pilgrimage in Europe on 17 March 1371 might easily have visited Becket's shrine as part of the obsequies of David himself; or the grouping of Sir Alexander Lindsay, Sir Patrick Hepburn, Sir John Abernethy, Sir John Edmonstone and John Towers en route to the Holy Land after December $1381 .{ }^{116}$ If one trend does suggest itself, though, amongst these passes, it is that very few Scottish churchmen were included in their number after 1371 and most of the laymen named were knights prominent in the Anglo-Scottish border warfare of the day. Indeed, their pilgrimage activity may have 
become integrated with, subsidiary to, or even merely an excuse for, military and chivalric pursuits.

For example, on 16 January 1383, Sir James Lindsay of Crawford was permitted to make pilgrimage to Becket's shrine at Canterbury but with a retinue of a hundred men, hinting strongly that his real purpose may have been attendance at a tournament: in May 1390 Lindsay and several other Scottish lords, would be given permission to enter England to buy armour. Similarly, on 16 March 1390, George, earl of March, secured permission to travel south to London for a single-combat against the earl of Nottingham: but on 28 October 1390, March was also granted a pass to Canterbury as was his brother, John, earl of Moray, on 20 December, documents which were presumably, though, not used as they seemed to be repeated on 13 June 1391. By 1406, Alexander Stewart, earl of Mar, was in receipt of passports which allowed him to travel either armed or unarmed. ${ }^{117}$ It was military activity or simply unstated 'business' which thus became the predominant purpose of safe-conduct requests in the later fourteenth-century: no extant passes explicitly to Canterbury were granted to Scots $c .1391-c .1400$.

Of course, it can never be known whether this apparent gradual decline of Scottish interest in Becket was reflected in the activity of lower-class Scottish pilgrims: it may be that they concentrated their devotions to St Thomas at Arbroath Abbey. The latter was a site, however, given only slight attention by Kings Robert II and Robert III and which suffered another major fire in 1380: the rebuilding of Arbroath's almonry chapel and further fabric expansion does, though, suggests sustained popular pilgrimage. ${ }^{118}$ Further investigation is required to illustrate whether or not Scottish interest in Becket and Canterbury revived after 1400, perhaps during the similar captivity in England of James I from 1406 and the relative peace of his adult reign (1424-37), or in similar 
periods of Anglo-Scottish calm up to the realms' respective Reformations of 1538 and 1560; or, as seems most likely, whether further instances of Anglo-Scottish tension did indeed combine to drastically reduce Scottish interest in the distant southern shrine, for example the open conflict or distrust which coincided with the three remaining Becket Translation Jubilees of 1420, 1470 and 1520.

A cursory survey of the (admittedly patchy) Scottish Rolls of the English Crown for extant safe-conducts issued to Scots for travel explicitly to Becket's tomb and Canterbury reveals only some thirty to forty named individual Scots (and their retinues) seeking passage between $c .1404$ and $c .1538 .{ }^{119}$ This would seem to suggest that by no means did Scottish interest in the chief English pilgrimage site and saint ever again approach the kind of level, or rest upon the kind of relations, to which the two Bruce kings had aspired in the fourteenth-century. This is a trend of decline which singular instances of Scottish devotion to Becket in the fifteenth century - such as the miracle cure granted at Canterbury to a pilgrim from Aberdeen in 1445 - cannot overturn. ${ }^{120}$

Nonetheless, to conclude, it is clear that far from becoming an embarrassing handicap in the struggle against England after 1296, St Thomas and his devotional centres of Arbroath and Canterbury had actually increased in their religious resonance and utility for many Scots, not least the Bruce kings. Robert I had clearly felt a strong familial and, possibly, a personal spiritual connection with St Thomas before 1307, one he turned increasingly to a strategic tack against English diplomacy and propaganda. The unexpected dynastic and diplomatic circumstances of David II's reign, however, saw Scottish Crown-sponsorship of devotion to Becket and to Canterbury and Arbroath continue to be driven by strategic and political motives but still fuelled by a genuine personal belief in the positive inter-cessionary powers of the saint - a faith shared by the 
king and a significant, active proportion of his subjects in pursuit of closer relations with England: this is a pattern still under-emphasised by most modern scholars of the later fourteenth-century. After 1357, for David, his councillors and numerous nobles, clerics, merchants and lesser Scots, there was clearly a reduced need for a confrontational antiEnglish advocacy of Becket's cult and a more general call for the saint's aid of livelihoods, general cures and shelter from epidemic. Had the Bruce dynasty survived its second generation, then, Scottish devotion and pilgrimage to St Thomas, as well as associated Anglo-Scottish trade, education, chivalric and cultural exchange, and, perhaps, resumed intermarriage and land-holding, might have formed a central component of the spirituality and identity of the Scottish court and wider community. These links might have emerged as the basis of far more pacific Anglo-Scottish contact than that which would be favoured by Stewart kings of Scots after 1371.

Michael Penman, University of Stirling.

The author is grateful to the Carnegie Trust for the Universities of Scotland for funding the archival research for this paper and for the comments of contributors to the War \& Peace: New Perspectives on Anglo-Scottish Relations colloquium held at the University of Durham in Sept. 2004 and of two anonymous referees. 


\section{NOTES}

${ }^{1}$ The literature in this area is substantial, e.g. A. Duggan, 'The Cult of St Thomas Becket in the Thirteenth Century', in M. Jancey ed., St Thomas Cantilupe, Bishop of Hereford: Essays in His Honour (Hereford, 1982), 21-46; A. Duggan, Reputations: Thomas Becket (London, 2004), 224-52; R. [Foreville, Le Jubilee] de Saint Thomas Becket du XIII au $X V^{e}$ siècle (1220-1470): Étude et Documents (Paris, 1958); R. [Foreville ed., Thomas Becket]: Actes du Colloque International de Sedieres (Paris, 1973); B. Nilson, Cathedral Shrines of Medieval England (Woodbridge, 1998), 147-54, 211-5.

${ }^{2}$ S.C. Wilson, 'Scottish Canterbury Pilgrims', Scottish Historical Review, xxiv (192627), 258-64.

${ }^{3}$ J. [Alexander and] P. [Binski eds., The Age of Chivalry]: Art in Plantagenet England, 1200-1400 (London, 1987), 220, no. 48; P. [Yeoman, Pilgrimage in Medieval Scotland] (London, 1999), 113-8. See also below n73.

${ }^{4}$ D. Webb, Pilgrims and Pilgrimage in the Medieval West (London 1999), ch. 10; D. Ditchburn, Scotland and Europe: the Medieval Kingdom and its Contacts with Christendom, 1214-1560: Volume I-Religion, Culture and Commerce (East Linton, 2000), 57-65.

${ }^{5}$ M. [Penman], The Bruce Dynasty in Scotland: [David II], 1329-71 (East Linton, 2004), $188-9,412-27$.

${ }^{6}$ A.J. [MacDonald, Border Bloodshed]: Scotland, England and France at War, 13691403 (East Linton, 2000), passim; D. McRoberts, 'The Scottish church and nationalism in the fifteenth century', Innes Review, xix (1968), 3-14.

${ }^{7}$ D. Webb, Pilgrimage in Medieval England (London, 2000), 96-7. 
${ }^{8}$ K.J. Stringer, 'Arbroath Abbey in Context, 1178-1320', in G.W.S. Barrow ed., The Declaration of Arbroath: History, Significance and Setting (Edinburgh, 2003), 116-41, at 122.

${ }^{9}$ F. Barlow, Thomas Becket (London, 1986), 225-50, 269-70; M. Staunton, The Lives of Thomas Becket (Manchester, 2001), 214-9; D.D.R. [Owen, William the Lion]: Kingship and Culture, 1143-1214 (East Linton, 1997), 59-62; E.L.G. [Stones, ed., Anglo-Scottish Relations], 1174-1329: Some Selected Documents (London, 1965), no. 1.

${ }^{10}$ Owen, William the Lion, 20-31, 154-82.

${ }^{11}$ William's genuine belief in Becket may be indicated by his reported dispatch of (Jocelin?) the bishop of Glasgow to investigate the miracle cure of a John of Roxburgh from drowning in the Tweed through St Thomas's intercession [J.C. Robertson ed., Materials for the History of Thomas Becket, Archbishop of Canterbury (Rolls Series, 7 vols, London, 1875-85), i, 296-8].

${ }^{12}$ C. Innes ed., [Liber S. Thome de Aberbrothoc] (2 vols, Bannatyne Club, Edinburgh, 1848-56), i, introduction; A.O. Anderson ed., Early Sources of Scottish History AD5001286 (2 vols, Stamford, 1990), ii, 289, 442 (the Chronicle of Melrose - the author of this work of c.1136-1274 was present at Becket's canonisation in 1173 [ibid, $277 \mathrm{n} 3]$ ). Interestingly, John of Fordun's chronicle, assembled c.1380, made no mention of Henry II's prayers to Becket in defeating William [Johannis de Fordun Chronica Gentis Scotorum [Chron. Fordun], ed. W.F. Skene (2 vols, Edinburgh, 1871), i, 263-4].

${ }^{13}$ R. Fawcett ed., Royal Dunfermline (Edinburgh, 2005), 27, 31, 177-8; A.A.M. Duncan, 'St Kentigern at Glasgow Cathedral in the Twelfth Century', in R. Fawcett ed., Medieval 
Art and Architecture in the Diocese of Glasgow (London, 1998), 9-24; and see above n11.

${ }^{14}$ D. Broun, 'The Church and the origins of Scottish independence in the twelfth century', Records of the Scottish Church History Society, xxxi (2002), 1-35.

${ }^{15}$ Liber S. Thome de Aberbrothoc, i, passim; Stones ed., Anglo-Scottish Relations, no. 2; Stringer, 'Arbroath Abbey in Context', 116-20.

${ }^{16}$ Duggan, 'Cult of St Thomas', 36-40.

${ }^{17}$ A.A.M. Duncan, The Kingship of the Scots, 842-1292: Succession and Independence (Edinburgh, 2002), chs. 4 and 6; Chron. Fordun, i, 305 [1278].

${ }^{18}$ E. Duffy, 'The dynamics of pilgrimage in late medieval England', in C. [Morris] and P. [Roberts eds., Pilgrimage]: the English Experience from Becket to Bunyan (Cambridge, 2002), 164-77, at 165. The Trans-National Database and Atlas of Saints' Cults project [TASC], based at the University of Leicester, emphasises the importance of fully contextualising any saint's cult and its devotions: see G. Jones, 'Comparative Research Rewarded: Religious Dedications in England, Wales and Catalunya', in idem ed., Saints of Europe: Studies towards a Survey of Cults and Culture (Donington, 2003), 210-60, at 211.

${ }^{19}$ Benedict of Peterborough recorded two Scots cured: Eda, a lady cured of lameness at Becket's tomb and John of Roxburgh, restored after drowning in the Tweed. William of Canterbury noted eight Scots cured, including Robert of the house of Huntingdon, whose brother fell ill after refusing to accompany him to Canterbury; Mary of Elgin in Moray and an unnamed blind person of the same shire; Margaret Hamilton, delivered from agonising childbirth by a vow of pilgrimage to Canterbury; John 'called the Scot', cured 
of leprosy; Robert and Henry 'two servants of the English and Scottish courts'; the wife of Osbern, 'a Scottish nobleman'; and, again, John of Roxburgh [Robertson ed., Materials for the History of Thomas Becket, i, 170, 195-6, 226, 296-8, 326-8, 384-5, 458, 478, 497 and ii, 225, 266]. Benedict also recorded the cure of a Robert de Broc (Bruce?) [ibid, 128]. The thirteenth-century miracles of St ÁEbbe of Coldingham record Becket’s cures of a crippled Edinburgh man, a blind Scotswoman (who actually visited a Becket shrine in London) and a deaf Lothian man, as well as a Gaelic-speaker who went to Canterbury to give thanks for his cure by ǼEbbe [R. [Bartlett ed.] and trans., The [Miracles] of Saint Ábbe of Coldingham and Saint Margaret of Scotland (Oxford, 2003), $33,37,45,65-7]$.

${ }^{20}$ Foreville Le Jubilee, 7-11, 89-91; P. Binski, Becket's Crown: Art and Imagination in Gothic England, 1170-1300 (London, 2004), 3-28, 129-31, 162-6

${ }^{21}$ [C]anterbury [C]athedral [A]rchive, Register E, f. 127a, no. 1 and f. 143r.; also undated in transcript at $[\mathrm{N}]$ ational [A]rchives of [S]cotland, RH1/2/36.

${ }^{22}$ CCA, Register E, f. 127a, nos. 2 and 3.

${ }^{23}[C]$ alendar of $[D]$ ocuments Relating to $[S]$ cotland, ed. J. Bain (4 vols, Edinburgh, 1881-88), ii, nos. 67 and 80; Stringer, 'Arbroath Abbey in Context', 121. Alexander II's journey may have been a return following his attendance at the 1220 Translation.

${ }^{24}$ CCA, Register B, f. 304v-5r; G.W.S. Barrow, 'A Scottish Collection at Canterbury', Scottish Historical Review, xxxi, (1952), 16-28, at 16-7.

${ }^{25}$ E.A. Abbott, St Thomas of Canterbury: His Death and Miracles (2 vols, London, 1898), i, 308 [leprosy]. 
${ }^{26}$ R.M. Blakely, 'The Brus Family in England and Scotland, 1100-1290' (unpublished Ph.D. thesis, University of Durham, 2000), 252-4; P.G.B. McNeil and H.L. MacQueen eds., Atlas of Scottish History to 1707, 418-22.

${ }^{27}$ Ibid, 421; H. Loxton, Pilgrimage to Canterbury (London, 1978), 142-3.

${ }^{28}$ M.F. Moore, The Lands of the Scottish Kings in England (London, 1915), 123-9.

${ }^{29}$ Stringer, 'Arbroath Abbey in Context', 119-20; Webb, Pilgrimage in Medieval England, 165-6.

${ }^{30}$ P.B. [Roberts, Thomas Becket in the Medieval Latin Preaching Tradition]: an Inventory of Sermons about St Thomas Becket c.1170-c.1400 (The Hague, 1992), 7-43, which details some 180 extant sermons which invoke some aspect of Becket's life and sainthood, although no Scottish examples survive. NAS RH12/25 is, though, a fragment of a missal of St Thomas of possible Scottish provenance; a fifteenth-century French Book of Hours with additions in a Scottish hand includes memoriae and miniatures of St Thomas [C.R. Borland ed., A Descriptive Catalogue of the Western Medieval Manuscripts in Edinburgh University Library (Edinburgh, 1916), no. 43].

${ }^{31}$ A.J. Taylor, 'Edward I and the Shrine of St Thomas of Canterbury', Journal of the British Archaeological Association, cxxxii (1979), 22-8; List \& Index Society no. 135, Itinerary of Edward I (London, 1977).

${ }^{32}$ B. Dobson, 'The Monks of Canterbury in the Later Middle Ages', in P. Collinson, N. Ramsay and M. Sparks eds., A History of Canterbury Cathedral (Canterbury/Oxford, 2002), 136.

${ }^{33}$ D.W. Burton, 'Requests for Prayers and Royal Propaganda', in Thirteenth Century England III, eds. P.R. Coss and S.D. Lloyd (Woodbridge, 1991), 25-36. 
${ }^{34}$ Stones ed., Anglo-Scottish Relations, no. 24; [Chron]icon de [Lanercost] (Maitland Club, Glasgow, 1839), 179. Balliol had dispatched the abbot of Arbroath to Edward I in early 1296 with his renunciation of homage [Stones, op. cit., no. 23].

${ }^{35}$ J. Stevenson, Documents Illustrative of the History of Scotland (2 vols, Edinburgh, 1870), ii, 144; Willelmi Rishanger, Chronica et Annales, ed. H.T. Riley (Rolls Series, London, 1865), i, 78 (my thanks to Dr Amanda Beam of the University of Stirling for this reference); $C D S$, ii, nos. 1413, 1441; Stringer, 'Arbroath Abbey in Context', 121-2. ${ }^{36}$ The [Chron]icle of Walter of [Guisborough], ed. H. Rothwell (Camden Society, $3^{\text {rd }}$ series, lxxxix, 1957, 295 - the exact form of the oath is not specified; [C]alendar of Entries in the $[P]$ apal $[R]$ egisters relating to Great Britain and Ireland: Petitions to the Pope, ed. W.H. Bliss and others (London 1896): Edward I, 1292-1301, 315.

${ }^{37}$ S. Taylor, 'The Cult of St Fillan in Scotland', in T.R. Liszka and L.E.M. Walker eds., The North Sea World in the Middle Ages: Studies in the Cultural History of NorthWestern Europe (Dublin, 2001), 175-210; R.W. Frank Jr., 'Shrine Rivalry in the North Sea World', in ibid, 230-42.

${ }^{38}$ K. William-Jones, 'Thomas Becket and Wales', Welsh History Review, 5 (1971), 35065.

${ }^{39}$ CCA, MS Scrapbooks, MS SB/c. 145; J. Higgitt, The Murthly Hours: Devotion, Literacy and Luxury in Paris, England and the Gaelic West (London, 2000), 19-21. ${ }^{40}$ CCA, DCc Eastry Correspondence, EC III/3.

${ }^{41}$ For example, CPR, Petitions: Edward I, 1292-1301, 33, 147, 151, including Edward's grants to Bruce (VI), both given at Canterbury in 1295, of permission to remarry and the office of Carlisle castle keeper; Calendar of Inquisitions Miscellaneous [Chancery] 
preserved in the Public Record Office: I - Henry III and Edward I (London, 1916), no. 808 , in which Bruce (VI) is recorded as seizing half a merk's worth of land of the Archbishop of Canterbury. This Bruce is said to have gone on pilgrimage to Walsingham just before his death [C. Rawcliffe, 'Curing Bodies and healing souls: pilgrimage and the sick in Medieval East Anglia', in Morris and Roberts eds., Pilgrimage, 108-40, at 127].

${ }^{42}$ For example, $C D S$, ii, nos. 1493, 1540.

${ }^{43}$ An inventory of Becket's altar gifts in 1316 recorded eight rings including a pair of large and small gold rings with black sapphires [J.W. Legg and W.H. St. John Hope, Inventories of Christchurch Canterbury (Westminster, 1902), 71]. Edward I had married Margaret of France at Canterbury in 1299; in 1302 Edward was at Canterbury on 14-18 and 22-25 June and 3-5 Oct. [Itinerary of Edward I].

${ }^{44}$ W. Benchley, 'Visits to Rochester and Chatham made by Royal, Noble and Distinguished Personages, English and Foreign, 1300-1783', Archaeologia Cantiana, vi, (1866), 43-6; Webb, Pilgrimage in Medieval England, 158.

${ }^{45}$ G.W.S. [Barrow, Robert Bruce] and the Community of the Realm of Scotland (4th edition, Edinburgh, 2005), 190-1 for the murder; $[R]$ egesta $[R]$ egnum $[S]$ cottorum: II the Acts of William I, 1165-1214, ed. G.W.S. Barrow (Edinburgh, 1971), no. 254 by which William I gave the Dumfries chapel dedicated to Becket into the patronage of Kelso Abbey, the mother house of Arbroath; J. [Mackinlay, Ancient Church Dedications] in Scotland: Volume II - Non-Scriptural (Glasgow, 1914), 280-5.

${ }^{46}$ M. Prestwich, Edward I (London 1988), 556-7; Scotichronicon by Walter Bower, ed. D.E.R. Watt et al (9 vols, Aberdeen, 1987-99) [Chron. Bower], vi, 331, written in the 
1440s, notes the date as the Translation feast of Thomas the Martyr, although Chron. Fordun, i, 344, assembled c. 1380, mistakes it for 5 Apr.

${ }^{47}$ RRS, v: The Acts of Robert I, 1306-29, ed. A.A.M. Duncan (Edinburgh, 1988), pp. 198203.

${ }^{48} \mathrm{Ibid}$, passim - these inferences can be made by working out upon which dates, regardless of calendar year, no (extant) act was issued by Robert I; J.B.L. Tolhurst, 'Notes on a Printed Breviary Used at Arbroath Abbey', Innes Review, vol. 5, no. 2 (1954), 104-18; Stringer, 'Arbroath Abbey in Context', 122.

${ }^{49} R R S, \mathrm{v}$, no. 74 [candles] and pp. 135-58 ['Itinerary'], which shows that although Robert I acta were issued from Forfar or Arbroath about Dec.-Jan. of 1314, 1315, 1316, $1318,1321,1322,1325,1326$ and 1327 , such place-dates surely represent the travels of the Chancellor until c. Mar. 1328, Abbot Bernard. Professor Duncan argues persuasively that even those acts issued from Forfar on 27 Dec. 1328 and 2 Jan. 1329 were proof only of the whereabouts of the great seal and Chancery; but - given that they are so far off the usual path of the then new Chancellor, Walter of Twynham - might these later acts not be the ailing king's movements, hinting at a final observance of Becket's feast on 29 Dec. 1328 [ibid, pp. 157 and nos. 360-61]?

${ }^{50}$ G.S. Gimson, 'Lion Hunt: a royal tomb-effigy at Arbroath Abbey', Proceedings of the Society of Antiquaries of Scotland, 125 (1995), 901-16. This article revises convincingly the earlier view that this statue (now minus its upper torso) was actually Becket [T. Borentius, St Thomas Becket in Art (London, 1932), 26]. 
${ }^{51}$ M. Prestwich, 'The Piety of Edward I', in W.M. Ormrod ed., England in the Thirteenth Century (Nottingham 1985), 120-8; Alexander and Binski eds., The Age of Chivalry, chs. ix-X.

${ }^{52}$ D. Perry, 'A new look at old Arbroath', Tayside and Fife Archaeological Journal, iv (1998), 260-78; D. McRoberts, 'The Cult of St Michael in Scotland', Millenaire Monastique du Mont Saint Michel, iii (1971), 471-9.

${ }^{53} R R S$, v, no. 29; D.H. Caldwell, 'The Monymusk Reliquary: the Breccbennach of St. Columba', Proceedings of the Society of Antiquaries of Scotland, 131 (2000), 262-82; Chron. Bower, vi, 363-5 [1314 speech]. The dozen additional altars within Arbroath Abbey included dedications to SS. Katherine of Alexandria, Peter, Lawrence, Nicholas and James.

${ }^{54}$ Stringer, 'Arbroath Abbey in Context', 137 n36. These relics at Arbroath may have included some of the martyr's bones which Archbishop Langton had distributed after the Translation of 1220, or blood and/or oil, personal affects, or even Becket's seal on letters sent to Scotland: none of the latter seem to have survived although Walter Bower was familiar with documents issued by Becket's chancery [Roberts, Thomas Becket in the Medieval Latin Preaching Tradition, 13; A. Duggan, 'Aspects of Anglo-Portuguese Relations in the Twelfth Century: Manuscripts, Relics, Decretals and the Cult of St Thomas Becket at Lorvăo, Alcobaca and Tomar', Portuguese Studies, 114 (1998), 1-19, at 3-5; eadem ed. and trans. The Correspondence of Thomas Becket, Archbishop of Canterbury, 1162-1170 (2 vols, Oxford, 2000), passim; Chron. Bower, iv, 295-7]. ${ }^{55} R R S$, v, nos. 4, 13-4, 19, 20, 22, 28-34, 49, 74-5, 112, 118, 132, 151, 153, 169, 175 , $203,213-4,219,221,241,260,280,376,390,402,455,505$. The war-torn border abbey 
of Melrose was, though, perhaps more favoured, receiving $£ 2,000$ in justice profits per annum after 1325, funds for a king's dish for poor clerks and the burial of the king's heart [ibid, nos. 269, 288, 380].

${ }^{56}$ Robert issued several of these grants on 1 March 1313 from Scotlandwell in west Fife, a hospital dedicated to St Thomas in the patronage of St Andrews Cathedral [Yeoman, Pilgrimage in Medieval Scotland, 57-9].

${ }^{57}$ Liber $S$. Thome de Aberbrothoc, i, ix-xxiii, nos. 37-8; RRS, v, no. 376; S. Cameron and A. Ross, 'The Treaty of Edinburgh and the Disinherited (1328-32), History, lxxxiv (1999), 237-56.

${ }^{58}$ J. Dowden, 'The Inventory of Ornaments, Jewels, Relicks, Vestments, Service Books \&c. belonging to the Cathedral Church of Glasgow in 1432, illustrated from various sources, and more particularly from the Inventories of the Cathedral of Aberdeen', PSAS, xxxiii (1898-99), 280-329, at 298-9; Chron. Bower, iv, 293-7; Registrum Episcopatus Glasguensis (Bannatyne Club, 2 vols, Edinburgh, 1843), ii, 329-39, 593-8; J. Durkan, 'Notes on Glasgow Cathedral', Innes Review, 21 (1970), 46-81, 60.

${ }^{59}$ CDS, iv, pp. 448-9; Papal Letters to Scotland: Benedict XIII of Avignon, 1394-1419, ed. F. McGurk (Scottish History Society, Edinburgh, 1976), 342; Duncan, 'St Kentigern at Glasgow Cathedral'; Yeoman, Pilgrimage in Medieval Scotland, 18-27; Robertson ed., Materials for the History of Thomas Becket, i, 296-8.

${ }^{60} R R S, \mathrm{v}$, no. 203.

${ }^{61}$ Chron. Bower, vi, 413, which asserts that on 5 July 1318 Robert also pledged 100 merks annually to St Andrews priory to commemorate that saint's aid in the victory of Bannockburn [RRS, v, no. 500]. 
${ }^{62} \mathrm{Ibid}$, passim, reveals that no (surviving) acts of Robert I were recorded as issued on 2930 June and 2, 5, 6, 7 and 13 July between 1306 and 1329.

${ }^{63}$ Ibid, nos. 137-9; Chron. Bower, vi, 413; M. Penman, 'The Kingship of Robert I', in M. Brown and R. Tanner eds., Essays in Honour of Norman Macdougall (Edinburgh, forthcoming). Extrapolation from Robert I's extant acts also suggests 'non-business days' on the following feasts/anniversaries: 1 Jan. (Circumcision); 17 Feb. (d. of Robert Bruce (II) and, in 1307, Thomas and Alexander Bruce); 19 March (d. Alexander III); 25 March (St Mark); 19 May (St Dunstan); 26 May (St Augustine of Canterbury); 9 June (St Columba); 17 June (d. David earl of Huntingdon); 20 June (birth of St Fillan); 23 June (Bannockburn, day one); 9 Aug. (Arbroath abbey foundation); 15 Aug. (Assumption of the Virgin); 26 Aug. (St Ninian); 29 Aug. (St John the Baptist's death); 31 Aug. (St Ninian's translation); 11 Sept. (battle of Stirling Bridge, 1297); 29 Sept. (St Michael); 9 Oct. (St Denis); 3 Nov. (St Malachy, an Irish saint observed by Robert Bruce (V)); 10 Nov. (St Leonard); 11 Nov. (St Martin); 25 Nov. (St Katherine of Alexandria); 30 Nov. (St Andrew); 21 Dec. (St Thomas, apostle); 27 Dec. (St John the Evangelist). For the application of this methodology to reveal possible devotions of David II see M. Penman, 'Christian Days and Knights: the Religious Devotions and Court of David II of Scotland, 1329-71', Historical Research, Vol. 75, no. 189 (Aug. 2002), 249-72, at 271-2.

${ }^{64}$ Barrow, Robert Bruce, 191-6.

${ }^{65}$ A.A.M. Duncan, Scotland: the Making of the Kingdom (Edinburgh, 1974), 122-3; Barrow, 'A Scottish Collection at Canterbury', 24-8.

${ }^{66}$ P.A. Wilson, 'The Cult of St Martin in the British Isles: with particular reference to Canterbury and Candida Casa [Whithorn]', Innes Review, xix (1968), 129-43. In 1326 
Robert I paid for a 'king's meal' for monks as well as food and clothes for paupers at Melrose to be served out every St Martin's day [RRS, v, no. 288].

${ }^{67}$ For example, $C D S$, ii, no. 1926 (1307); M. Strickland, 'A Law of Arms or a Law of Treason? Conduct in War in Edward I's Campaigns in Scotland, 1296-1307', in R.W. Kaeuper ed., Violence in Medieval Society (Woodbridge, 2000), 39-78, at 41.

${ }^{68}$ Webb, Pilgrimage in Medieval England, 50-8, which also illustrates how late twelfthand early thirteenth-century writings on behalf of Canterbury often proclaimed St Thomas's success in a cure where another (rival) saint and shrine had failed. The dozen or so other dedications to Becket in Scotland may also have played a part in this networking, including altars in Brechin cathedral, St Giles church in Edinburgh, Kinloss Abbey (Moray), the parish churches of Perth, Dundee, Irvine (Ayrshire) and Glamis [Mackinlay, Ancient Church Dedications, ii, 285-6] and a chapel at Harlaw, Roxburghshire [RRS, ii, no. 379, which William I also gifted to Kelso Abbey on 4 July 1195 and which was perhaps associated with the miracle of John of Roxburgh - see above n11]. The miracles of St Ǽbbe of Coldingham included instances where Scots had received a vision of Ǽbbe urging them to make pilgrimage to Canterbury [Bartlett, ed., Miracles, 67].

${ }^{69}$ Chron. Bower, vi, 387 [Remonstrance] and vii, 5-7 [Declaration, 'given at our monastery of Arbroath']. The Declaration - which was accompanied by letters (now lost) from the Scottish king and bishops - was echoed by later epitaphs which compared Robert I to Judas Maccabeus, a champion against temporal tyranny to whom Becket was also often likened [Chron. Bower, vii, 47, 164, 173; Roberts, Thomas Becket in the Medieval Latin Preaching Tradition, 22]. Was the presence of St Thomas's priory, 
Dublin, also the reason why the Scots seemed so reluctant to attempt to take that city in their Irish campaigns of 1315-18?

${ }^{70}$ T.A. Sandquist, 'The Holy Oil of St Thomas of Canterbury', in M.R. Powicke and T.A. Sandquist eds., Essays in Medieval History Presented to Bertie Wilkinson (Toronto, 1967), 330-44; J. Burden, 'How Do You Bury a Deposed King? The Funeral of Richard II and the Establishment of Lancastrian Royal Authority in 1400', in G. Dodd and D. Biggs eds., Henry IV: the Establishment of the Regime, 1399-1406 (Woodbridge, 2003), 35-54. Edward II can be found at Canterbury on at least sixteen occasions in his reign [List \& Index Society: Volume 211 - The Itinerary of Edward II and his Household, 1307-28 (London, 1984)].

${ }^{71} R R S$, v, no. 118 (this was the only occasion when one of Robert I's extant acts was issued on a 24 June).

${ }^{72}$ NAS, GD 40/1/41, a Lindsay grant witnessed by Robert Keith the Marischal, Robert Lauder the Justiciar of Lothian, Robert Bard the sheriff of Lanark, Sir Henry Sinclair, a Robert Logan and Sir Alexander Lindsay.

${ }^{73}$ Registrum Episcopatus Moraviensis (Bannatyne Club, Edinburgh, 1837), no. 224; Stringer, 'Arbroath Abbey in Context', 123. Randolph's interest in Becket at Elgin may rest upon earlier devotional associations: William of Canterbury recorded two miracles at Elgin where a chaplain's false use of ordinary holy water to treat a Mary of Elgin instead of 'water of St Thomas' (presumably in an ampule obtained through pilgrimage to Canterbury) was exposed by a vision of St Thomas and the rightful oil found in the bishop of Moray's house at Spynie: Bishop Simon de Toney of Moray (1172-84) - a former monk of Melrose, abbot of Coggeshall in Essex and a fellow Cistercian of Jocelin 
of Glasgow - also cured blindness with a phial of water which had been dipped in ' $\mathrm{St}$ Thomas's water'. Simon was presumably a member of the de Tosny family of Sussex nobles related to the Warenne family: he was succeeded in Moray by Richard of Lincoln (1184-1203) [Robertson ed., Materials for the History of Thomas Becket, i, 384-5; Chron. Bower, iv, 291-3; G.W.S. Barrow, The Anglo-Norman Era in Scottish History (Oxford, 1980), 109-10].

${ }^{74}$ Stones ed., Anglo-Scottish Relations, no. 41; CDS, ii, no. 991 (Douglas's safe-conduct, valid for 7 years); Penman, 'The Kingship of Robert I'.

${ }^{75}$ [Rot]uli [Scot]iae in Turri Londinensi et in Domo Capitulari Westmonasteriensi Asservati, ed. D. Macpherson (2 vols, London, 1814-19), i, 200-821; M. Penman, 'A fell conuiracioun again Robert ye douchty king: the Soules conspiracy of 1318-20', Innes Review, 1 (1999), 25-57. Edward Balliol may have been present at the 1320 Jubilee. ${ }^{76}$ A.K. McHardy, 'Some Reflections on Edward III's Use of Propaganda', in J.S. Bothwell ed., The Age of Edward III (Woodbridge, 2001), 171-92, at 182.

${ }^{77}$ Penman, David II, 52-3, 64, 71, 78; R. Foreville, 'Le culte de saint Thomas Becket en Normandie' and idem, 'Le culte de saint Thomas Becket en France', in idem ed., Thomas Becket, 135-52 and 163-88. See Robertson ed., Materials for the History of Thomas Becket, ii, 268 for an example of Becket miracles in Rouen.

${ }^{78}$ RRS, vi: the Acts of David II, 1329-71, ed. B. Webster (Edinburgh, 1982), nos. 25-6. David made use of such relics as a Holy Cross fragment of St Margaret as battle standards [Penman, David II, 128].

${ }^{79}$ M.A.E. Green, Lives of the Princesses of England (6 vols, London, 1849-55), iii, 11459. 
${ }^{80}$ W.M. Ormrod, 'The Personal Religion of Edward III', Speculum, 64 (1989), 849-77, at 858; Webb, Pilgrimage in Medieval England, 130-3, 202-3; Dobson, 'The Monks of Canterbury', 145. For miracle releases granted by St Thomas to prisoners see Robertson ed., Materials for the History of Thomas Becket, ii, 270-9.

${ }^{81}$ [N] ational [A]rchives [Kew] E403/387 m. 28; CDS, iii, no. 1610; E.W.M. BalfourMelville, 'Papers Relating to the Captivity of David II', Scottish History Society Miscellany IX (Edinburgh, 1966), 9-35, at 29; Penman, David II, ch. 6. David spent much of 1353-57 at Odiham castle, Hampshire, close to the western end of the RochesterCanterbury pilgrim route. He may also have visited Canterbury in Jan. 1357 [British Library, Add. MSS. 24, 512, f.4-6].

${ }^{82}$ The $[$ E]xchequer $[R]$ olls of Scotland, eds. J. Stuart et. al. (23 vols, Edinburgh, 18781908), i, 591. Robert I's account rolls are missing save for those of 1328-29.

${ }^{83}$ J.D. Robertson, A Handbook of the Coinage of Scotland (London, 1878), 3; Nilson, Cathedral Shrines of Medieval England, 107-9.

${ }^{84}$ Litterae Cantuariensis, ed. J.B. Sheppard (3 vols, Rolls Series, London, 1887-9), ii, no. 851. David was at Arbroath on 14 May 1358 [RRS, vi, no. 182].

${ }^{85}$ ER, ii, 6 ('Richard the Englishman'); CPR: Petitions to the Pope, Vol. i, 1342-1419, 331. By May 1363, Ellisworth could be found in the patronage of John of Brittany again seeking a Canterbury benefice [ibid, 420].

${ }^{86}$ Rot. Scot., i, 884, 887, 892, 899, 900, 917; Queen Margaret also requested passage to Canterbury with her own retinue in 1364 [ibid, 881].

${ }^{87}$ Ibid, 828 [July 1359], 872 [Apr. 1363], 881 [Feb. 1364, to Walsingham with thirty followers], 928 [Mar. 1369], 937 [Feb. 1370]; Penman, David II, 221-2, 301-8, 338-49, 
383-6. David had been wounded with two arrows in the head in 1346: thus he was perhaps particularly interested in Becket's corona shrine which held his severed skullcrown at Canterbury. St Thomas had certainly cured arrow wounds in others [e.g. Robertson ed., Materials for the History of Thomas Becket, ii, 279-81]. ${ }^{88} R R S$, vi, nos. 470-2; ER, ii, 356; Penman, David II, 407-12. On 15 June 1370, at Westminster, Edward III granted 'at the request of the King of Scotland', a pardon for one of the alleged killers of John de Coupland, David's captor in 1346 [Calendar of Patent Rolls, $1232-1509$ (52 vols, London, 1891-1906): Edward III 1367-70, 431]. Edward himself gave $£ 16$ 13/- 4d in alms at Canterbury in 1370 and seems to have given $£ 40$ to Scottish knightly and clerical companions of David II about the same time [NA, E403/440 m. 9 and m. 17].

${ }^{89}$ For 1357 to $c$. Feb. 1371: Rot. Scot., i, 821 [Thomas Macolagh], 824 [Thomas and Gilbert Macolagh], 828 [John Goldsmith], 833 [Sir Hugh Eglintoun, Sir Archibald Douglas], 840 [William, earl of Douglas], 841 [Patrick, earl of March], 842 [Sir William More, Adam Tyningham], 852 and 856 [Thomas Macolagh and wife], 859 [Patrick, earl of March], 865 [the Bishop of St Andrews, William, earl of Douglas (twice that year, 1362), Thomas Somerville, Patrick, earl of March, Robert of Caithness, Thomas earl of Mar, Sir William Ruthven, Hamelinus Leslie, Thomas Leith a burgess of Linlithgow], 872 [Patrick, earl of March, Sir Thomas Somerville, John Ross, Sir Hugh Eglintoun, Sir Duncan Wallace, Sir Patrick Hepburn, Alexander bishop of Aberdeen, Sir William Ruthven], 878 [Patrick, earl of March], 880 [Thomas, earl of Mar], 883 [Sir Robert Maxwell, Sir Thomas Somerville], 929 [Sir Thomas Somerville]. For post Feb. 1371: ibid, 955 [George, earl of March, John Wardlaw], 960 [James Douglas, Eleanor Countess 
of Carrick], 962 [Thomas Rate], 963 [Sir Henry Douglas], 970 [Margaret, Countess of Douglas]; ii, 41 [Sir John Herries], 46 [Sir James Lindsay], 86-7 [George, earl of March], 103 [Sir Henry Preston]; 108 [John, earl of Moray]. Foedera, Conventiones, Litterae et Cuiuscunque Generis Acta Publica, ed. T. Rymer (20 vols, London, 1704-35), ii, 550, also lists Walter Stewart earl of Atholl's receipt of a conduct on 8 June 1404.

${ }^{90}$ Webb, Pilgrimage in Medieval England, 228.

${ }^{91}$ Pilgrims often attended the first Becket Translation feast after a loved-one's death [ibid, 193].

${ }^{92}$ Penman, David II, 277-9, 407. The relatively high incidence of 'Thomas' as a Christian name among Bruce supporters of these generations is remarkable: e.g. Thomas Randolph (x2), Thomas Bruce of Clackmannan (a bastard nephew of Robert I), Thomas of Mar, Thomas of Angus, Thomas Murray of Bothwell (a nephew of Robert I), Thomas Erskine, Thomas Balliol, Thomas Barry, Thomas Menzies, Thomas Somerville, Thomas Roter (a herald of David II), Thomas Bisset of Upsetlington/Fife [ibid, ad indicem].

${ }^{93}$ Rot. Scot., i, 811, 817, 819, 826, 830; Chron. Fordun, i, 375-6.

${ }^{94}$ Calendar of Papal Registers relating to Great Britain and Ireland: Papal Letters, Vol. IV, 1362-1404, eds. W.H. Bliss and J.A. Twemlow (London, 1902), 42 (10 Feb. 1364); S. Boardman, The Early Stewart Kings: Robert II and Robert III, 1371-1406 (East Linton, 1996), 72-9.

${ }^{95}$ CDS, iii, nos. 198, 215, 458, 550; J.B. Paul ed., The Scots Peerage (9 vols, Edinburgh, 1904-14), ii, 436-7.

${ }^{96}$ Rot. Scot, i, 893; similar groupings recur in Nov. 1364, Oct. 1365, Mar. 1366, Oct. 1366, Jan. 1368 and June 1369 [ibid, 886, 897, 901, 905, 915, 919, 932]. 
${ }^{97}$ Ibid, 876-9; Penman, David II, 301-8.

${ }^{98}$ Duffy, 'The dynamics of pilgrimage', 164-5.

${ }^{99}$ Penman, David II, chs. 7 to 9 passim.

${ }^{100}$ Rot. Scot., i, 815; Watt, Scottish Graduates, 8-9, 34, 54, 60-1, 243-6, 498, 535-6.

Professor Anthony Goodman, Emeritus at Edinburgh University, has pointed out to me that some clerics may have been given to study at Oxford and Canterbury (not Cambridge) [e.g. 12 clerics in Dec. 1380 - Rot. Scot., ii, 31].

${ }^{101}$ Ibid., i, 816, 860. David II and Hogg co-founded an altar to St Katherine in St Giles church in Edinburgh in 1358 [RRS, vi, no. 204].

${ }^{102}$ Penman, 'Christian Days and Knights', 261-8.

${ }^{103}$ The occasional parliamentary prohibition on Scottish travel abroad suggests individuals did have to go through the Scottish government first [Records of the Parliaments of Scotland (St Andrews, forthcoming), 1370/2/37 ('Item, that the burgesses or merchants shall not remove themselves from the kingdom unless they have requested and obtained permission from our lord king or the chamberlain')] as do letters by Scottish Guardians and David II in requesting travel passes through England for named Scottish ambassadors [RRS, vi, nos 9, 493, 499, 502, 510].

${ }^{104}$ See $n 89$ above.

${ }^{105}$ Rot. Scot., i, 865-6 [Mar becomes Edward III's man]; Penman, David II, chs. 8-9 passim. The periodic absence of these nobles as crown charter witnesses in Scotland suggests they may indeed have used some of these permits [RRS, vi, passim]. ${ }^{106}$ Rot. Scot., i, 872. 
${ }^{107}$ The Dunbars of March had frequently supported the English Crown c.1296-c.1335 and George, tenth earl of March, would defect to Henry IV, his cousin, in 1400; the Douglases, like the Dunbars, had held lands in England before 1296, recovered some English lands briefly c.1330-32 and would also defect to England in 1455 [M. Brown, The Black Douglases: War and Lordship in Late Medieval Scotland, 1300-1455 (East Linton, 1998), 13, 25-7, 99-105]. Some indication of close spiritual ties between southern Scotland and England despite war may lie in evidence for north-west English interest in St Ninian at Whithorn [Webb, Pilgrims and Pilgrimage, 215] and the apparent Yorkshire masons' influence on building work at Melrose c.1380-1420; fifteenth-century Scots also continued to show a strong interest in St Cuthbert's cult at Durham with many Scottish church dedications to this saint [my thanks to Dr Richard Oram of the University of Stirling and to Professor Anthony Goodman for these points respectively].

${ }^{108}$ The Original Chronicle of Andrew of Wyntoun, ed. A. Amours (Scottish Text Society, 6 vols, Edinburgh, 1903-14), v, 42. John Maior, Scottish theology professor at Paris and St Andrews in the early sixteenth-century, could still assert: 'Arbroath, a community, I say, second in wealth to none in Scotland, and indeed I know not if there be one more richly endowed in all Britain' [A History of Greater Britain, 1521, ed. A. Constable (Scottish History Society, Edinburgh, 1892), 165].

${ }^{109}$ See $n 89$ above.

${ }^{110}$ MacDonald, Border Bloodshed, for all these events.

${ }^{111}$ Chron. Bower, vii, 391-449 and viii, 21-57; Webb, Pilgrimage in Medieval England, 171-5. However, John of Gaunt, exiled to Scotland briefly in 1381, did issue conducts to Canterbury to the abbot of Holyrood and Sir William Cunningham in Dec. 1381 [John of 
Gaunt's Register, 1379-1383, eds E.C. Lodge and R. Somerville (2 vols, London, Camden $3^{\text {rd }}$ series, lvii, 1937), nos 1192, 1195]: my thanks to Professor Anthony Goodman for these references.

${ }^{112}$ Sandquist, 'The Holy Oil of St Thomas at Canterbury'.

${ }^{113}$ R. Nicholson, Scotland: the Later Middle Ages (1974), chs. 8-9.

${ }^{114}$ Alexander and Binski eds., The Age of Chivalry, 222, no. 68. Henry IV would also be buried at Canterbury as was Thomas, Duke of Clarence, after his death in battle against the Scots at Baugé in 1421: thus Scots may have been less welcome at Becket's shrine after the Jubilee year of 1420 [A History of Canterbury Cathedral, 419; D.M. Palliser, 'Royal Mausolea in the Long Fourteenth Century (1272-1422)', in W.M. Ormrod ed., Fourteenth Century England III (Woodbridge, 2004), 1-15].

${ }^{115}$ Rot. Scot., i, 942- and ii, 1-175, passim.

${ }^{116} \mathrm{Ibid}, \mathrm{i}, 943-4$ and ii, 40.

${ }^{117}$ Ibid., ii, 46, 193, 108, 177; Chron. Bower, vii, 9-19. Alternatively, George and John may have felt guilty about being absent from defending Elgin cathedral and its Becket chaplainries in their family's earldom of Moray from the attack of Alexander Stewart, the 'Wolf of Badenoch', in summer 1390.

${ }^{118}$ ER, iii, 297; Chron. Bower, vii, 381; Perry, 'A new look at old Arbroath', 260-78. ${ }^{119}$ Rot. Scot. ii, 192-3, 200, 252, 347, 349, 354-5, 357, 358, 375, 419; Foedera, ii, 550, 685; Webb, Pilgrims and Pilgrimage, 221-4.

${ }^{120}$ Aberdonian Alexander Stephenson was cured of diseased feet at Canterbury about 7 July 1445, as witnessed by three Scottish companions and the chapter [ibid, 221-2; Robertson ed., Materials for the History of Thomas Becket, ii, 295]. 